\title{
Equality Bodies: advancing towards more responsive designs?
}

\author{
Sara Benedi Lahuerta* \\ Assistant Professor in Law, Sutherland School of Law, University College Ireland (UCD), Republic of Ireland \\ ${ }^{\star}$ Corresponding author. E-mail: Sara.benedilahuerta@ucd.ie
}

\begin{abstract}
The EU has progressively introduced antidiscrimination enforcement measures like the duty to set up Equality Bodies (EBs) that applies to the ground of racial or ethnic origin, among others. Until recently, however, EU law only envisaged vague standards for EBs that allowed a wide range of national configurations. Building on international benchmarks, this paper draws a set of dimensions considered necessary to improve promotion-type EBs responsiveness to discrimination. These dimensions are applied to the British and Spanish EBs to illustrate how the gaps left by EU law may lead to the design of ineffective bodies. The paper argues that EBs can contribute to effectively tackling discrimination if they are designed to be responsive at individual and systemic levels. The 2018 EU Recommendation on Standards for EBs makes a step forward in that direction, but its practical relevance may be limited by its non-binding nature.
\end{abstract}

Keywords: antidiscrimination law; sociology; Equality Bodies; standards; enforcement; Racial Equality Directive

\section{Introduction}

EU law has had a substantial impact in the development of antidiscrimination law in Member States ('MS'). ${ }^{1}$ Crucially, it has influenced both substantive provisions and enforcement mechanisms. After the entry into force of the Treaty of Amsterdam, the EU was able to adopt the 'Racial Equality Directive' (RED) and the 'Framework Equality Directive' (FED). ${ }^{2}$ Among other merits, ${ }^{3}$ these Directives expanded the list of protected grounds ${ }^{4}$ and introduced novel enforcement requirements. In particular, the RED established a duty to set up Equality Bodies (EBs) in the field of ethnic-origin or racial discrimination. ${ }^{5}$ This duty was later extended to other - although not all ${ }^{6}$ - discrimination grounds, namely sex and nationality discrimination for mobile workers.

Whilst the initial transposition of the EU mandate to set up EBs was 'fraught' and 'uneven', it eventually led to the creation of a wealth of EBs and/or the consolidation of existing

\footnotetext{
${ }^{1}$ See e.g. Bleich (2003) on Britain and France, Solanke (2009, pp. 53-79) on Britain and Germany and, more generally, Van Ballegooij and Moxom (2018).

${ }^{2}$ Directives 2000/43/EC ('RED') and 2000/78/EC ('Framework Directive'). This was possible thanks to the insertion of current Art. 19 TFEU; see further Bell (2001).

${ }^{3}$ Bell, supra note 2 .

${ }^{4}$ To include not only sex, but also racial or ethnic origin, religion or belief, disability, age and sexual orientation, Arts 1 RED and 1 FED.

${ }^{5}$ Art. 13 RED. This provision was partly inspired by the European Commission against Racism and Intolerance (ECRI)'s General Policy Recommendation No. 2 (CRI(97) 36, 13 June 1997).

${ }^{6}$ See criticism in Kádár (2018); Benedi Lahuerta (2020).

${ }^{7}$ Directives 2004/113/EC ('Gender equality in access to goods and services'), Art. 12; 2006/54/EC ('Recast Employment Directive'), Art. 20; 2010/41/EU ('Gender equality for the self-employed'), Art. 11; and 2014/54/EU ('Enforcement of Mobile workers' rights'), Art 4. (hereinafter, 'EU Directives').

${ }^{8}$ Givens and Case (2014, p. 13).

(c) The Author(s), 2021. Published by Cambridge University Press. This is an Open Access article, distributed under the terms of the Creative Commons Attribution licence (https://creativecommons.org/licenses/by/4.0/), which permits unrestricted re-use, distribution, and reproduction in any medium, provided the original work is properly cited.
} 
ones. ${ }^{9}$ However, this trend shifted with the 2008 financial and economic crisis, which led to budget cuts for many EBs as well as various changes in their institutional architecture ${ }^{10}$ that put various EBs in difficulty to perform their functions effectively (Ammer et al., 2010, pp. 78, 141-142; Equinet, 2012). Following various EU Directives' implementation reports ${ }^{11}$ and a campaign launched by the European Network of Equality Bodies ('Equinet') (2016), it became obvious that the divergences between national EBs and the challenges they faced were partly due to the vague provisions contained in EU Directives and that clearer EU standards for EBs were needed. To encourage the design of more effective EBs, the EU adopted in 2018 the 'Commission Recommendation on Standards for EBs' ('the Recommendation'). ${ }^{12}$

This paper deals precisely with EBs as one of the tools available to policy-makers to enforce antidiscrimination law. ${ }^{13}$ The central argument made here is that EBs can be crucial institutions to effectively 'respond' to discrimination, if appropriately designed and resourced. The paper focuses on 'promotion-type' EBs (i.e. those mainly seeking to support victims, raising awareness and promoting good practice $)^{14}$ with competences in the field of ethnic-origin or racial discrimination. ${ }^{15}$

The starting point of the analysis are international benchmarks on EBs, which are used to draw a 'Responsiveness Framework' that sets the key dimensions for equality watchdogs to effectively support individuals' reactions to ethnic-origin or racial discrimination and to promote equality ${ }^{16}$ in this field (section 2). This framework is then used to prove the RED's inability to yield national implementation approaches leading to the design of responsive EBs (section 3). This is further demonstrated with a case-study that applies the responsiveness dimensions to the British and the Spanish EBs (section 4). The paper concludes by briefly considering the standards set by the 2018 Recommendation and its potential to encourage the design of more responsive EBs (section 5).

From a methodological perspective, this work combines a 'law in the books' and 'law in action' approach. The former is based on the study of international instruments, as well as EU law and national law, whereas the 'law in action' analysis builds on the comparison between the British and Spanish EBs. This case-study draws on semi-structured interviews of key national experts and intermediaries in close contact with EBs and actual or potential victims of discrimination, ${ }^{17}$ grey literature reports and reliable information published by public bodies, national EBs and Equinet. ${ }^{18}$

\footnotetext{
${ }^{9}$ Before EU requirements were introduced, $20 \mathrm{MS}$ did not have EBs in place (Van Ballegooij and Moxom, 2018, p. 22). See also Holtmaat (2006); Ambrus (2012, pp. 330-331). On the influence of EU law in the development of EBs in Europe, see Benedi Lahuerta (forthcoming in 2022).

${ }^{10}$ E.g. mergers; see Crowley (2016); Crowther and O'Cinneide (2019); and more generally Farrell (2013).

${ }^{11}$ See Joint Reports $\operatorname{COM}(2014) 2$ final and $\operatorname{COM}(2015) 190$ final; Reports $\operatorname{COM}(2017) 671$ final and $\operatorname{COM}(2017) 678$ final; Midterm review COM(2017) 458 final; Parliament (EU) Resolution 2014/2160(INI).

${ }^{12} \mathrm{C}(2018) 3850$ final; see the justification for the adoption of the Recommendation in Recitals 18-28.

${ }^{13}$ Effectively addressing the complexities of discrimination requires a diverse 'policy mix', in which many other tools may be useful; see e.g. Alfinito Vieira and Graser (2015).

${ }^{14}$ Some countries have established instead tribunal-type EBs, which focus mainly on hearing, investigating and deciding complaints, or even bodies that combine promotion and adjudicating functions; see further Ammer et al. (2010, pp. 43-44, Table 2.1).

${ }^{15}$ However, most of the analysis could be applied more widely because challenges faced by EBs are similar for other protected grounds.

${ }^{16}$ The abstract distinction between 'discrimination' and 'equality' is not always obvious (see McColgan, 2014, pp. 14-15). In this work, the negative notion of 'discrimination' means treating someone unfavourably due to their link with a 'forbidden ground', as defined in antidiscrimination law. In contrast, 'equality' has a positive connotation and refers to 'the belief in the equal worth of all human beings' so they all deserve being treated with equal concern and respect (Smith, 2011, pp. 1-11). Whilst socio-economic inequalities can affect ethnic minority groups, the idea of distributive or economic equality is not dealt with in this paper.

${ }^{17}$ See Appendix.

${ }^{18}$ These mixed sources are recommended for the study of ombudsmen by Seneviratne (2005). Conducting interviews with actual/potential victims could bring an additional 'law in action' perspective, but it was not feasible for this project due to limited resources.
} 
Before embarking on further discussion, a few terminological clarifications are needed. The term 'responsiveness' has been used in the literature with different meanings. Yesilkagit and Snijders (2008) consider that EBs are 'responsive' when they respond to all democratic preferences and to the demands of 'multiple political stakeholders. ${ }^{19}$ In this paper, that concept of responsiveness is embedded in the 'independence' dimension. ${ }^{20}$ For our purposes, the term 'responsiveness' is borrowed from Fineman's idea of the 'responsive state' (i.e. that state institutions have the onus to 'respond' to human vulnerability), which she developed in the context of her vulnerability theory (2008, pp. 1922 ). That concept has been taken forward by capability scholars, like Mackenzie, ${ }^{21}$ who alerts that the idea of vulnerability should not be used to develop 'coercive and objectionably paternalistic social relations' (Mackenzie, 2014, p. 34). She suggests that, in a theory of justice, the state's 'duty to protect must be informed by the overall background aim of enabling the development of ... autonomy, wherever possible' (Mackenzie, 2014, p. 35). Accordingly, the role of public institutions should be to help 'foster the development of the autonomy competences and capabilities necessary for functioning as an equal citizen in a democratic state' (Mackenzie, 2014, p. 34, citing Anderson, 1999, p. 316). Building on these ideas, the expression 'responsiveness' is used in this paper to argue that the state's duty to tackle discrimination and promote equality can more effectively be pursued relying on EBs. Provided that these institutions are appropriately designed and resourced, they can be key tools to effectively 'respond' to discrimination by both addressing it reactively, once it has occurred, and proactively, through strategies to promote equality. Thus, EBs can not only strategically act and campaign for equal treatment ('top responsiveness'), but also support and empower vulnerable individuals to become more autonomous in fighting discrimination ('bottom responsiveness').

In this context, the term 'effectiveness' is used with a double meaning. First, it refers to strategies linked to 'top responsiveness' that work to promote equal treatment and maximise the prevention of discrimination ('ex ante effectiveness'). Second, it evokes tools and approaches deemed to minimise the impact of discrimination once it has occurred (ex post effectiveness), which are connected to 'bottom responsiveness'. Most European legal systems are strongly based on reactive and individual enforcement models (Bell, 2008; Fredman, 2012) so, as the next section elucidates, the development of standards to boost EBs' responsiveness (top/bottom) must incorporate these two types of effectiveness (ex ante/ex post) (Benedi Lahuerta, 2014).

\section{The 'Responsiveness Framework' for the institutional design of EBs}

To ensure that EBs are responsive to discrimination in a way that fosters vulnerable groups' autonomy, their institutional design should ideally be approached looking at the actual issues arising at the grassroots level. These issues, and the corresponding design of EBs, will naturally change according to the social context. Nevertheless, there are a number of 'discrimination challenges' that are widespread in many jurisdictions, like the lack of awareness about antidiscrimination legislation (FRA, 2017), the inability to recognise what is discrimination (Citizens' Advice Bureau interview, 6 June 2018; see Appendix) and/or how to take action against it (FRA, 2012; 2017), the persistence of systemic discrimination, ${ }^{22}$ stigma (Solanke, 2017) and discriminatory biases (Alfinito Vieira and Graser, 2015). It is also widely documented that individuals who feel discriminated against tend not to report those behaviours ${ }^{23}$

\footnotetext{
${ }^{19}$ These authors argue that EBs should be 'impartial and responsive at the same time'. For instance, if they lack independence, they may be subject to micro-managing by the parent government department; yet, if EBs' independence is too broad, they may unduly identify with the cause(s) of specific interest groups; Yesilkagit and Snijders (2008, pp. 13, 36-37, 42).

${ }^{20}$ See section 2.

${ }^{21}$ See also Anderson (1999, p. 316); Ben-Ishai (2012); Robeyns (2018).

${ }^{22}$ See e.g. Macpherson (1999); Feagin (2013); Martínez (2014); Solanke (2017, p. 33).

${ }^{23}$ This is commonly known as 'underreporting' (e.g. Genn, 1999, p. 12; RED2RED, 2011, p. 94; Alderson, 2015; Barmes, 2016) or 'lumping' (Felstiner, 1974, p. 81). It has also been proved, however, that some ethnic groups are more likely to report discrimination than others (Blodorn and O'Brien, 2013) and that individuals may report discrimination incidents that do not correspond to what is legally defined as 'discrimination' (SAV, 2016, p. 43).
} 
Table 1. Responsiveness Framework for the institutional design of EBs

\begin{tabular}{|c|c|c|}
\hline $\begin{array}{l}\text { Responsiveness } \\
\text { level }\end{array}$ & Dimension & Subdimensions \\
\hline \multirow[t]{2}{*}{ 1. General } & A. Independence & $\begin{array}{l}\text { i. De jure independence } \\
\text { ii. De facto independence }\end{array}$ \\
\hline & B. Resources & $\begin{array}{l}\text { i. Enough resources to perform all functions } \\
\text { effectively } \\
\text { ii. Ringfencing of resources (protection against } \\
\text { arbitrary reduction) }\end{array}$ \\
\hline \multirow[t]{2}{*}{ 2. Bottom } & A. Accessibility & $\begin{array}{l}\text { i. Awareness-raising initiatives and outreach } \\
\text { campaigns } \\
\text { ii. Lessening external barriers to access EBs' } \\
\text { services }\end{array}$ \\
\hline & $\begin{array}{l}\text { B. Support services for } \\
\text { alleged victims }\end{array}$ & $\begin{array}{l}\text { i. Non-legal support } \\
\text { ii. Legal assistance } \\
\text { iii. Legal advice } \\
\text { iv. Legal representation/(strategic) litigation }\end{array}$ \\
\hline \multirow[t]{2}{*}{ 3. Top } & A. Systemic action & $\begin{array}{l}\text { i. Collecting information } \\
\text { ii. Launching equality-promotion actions } \\
\text { iii. Advisory function }\end{array}$ \\
\hline & B. Co-ordination & $\begin{array}{l}\text { i. Co-ordination with other key national/ } \\
\text { international stakeholders }\end{array}$ \\
\hline
\end{tabular}

Source: Author's own elaboration.

due not only personal motives, but also for fear of retaliation, ${ }^{24}$ mistrust in the legal system ${ }^{25}$ and lack of resources and/or understanding of complex legal terms and procedures. ${ }^{26}$ It is also common ground that EBs can play a key role in promoting a better enforcement of antidiscrimination legislation and in addressing these challenges if they are appropriately designed and 'they are given the necessary powers and resources' (Kádár, 2018 p. 147). ${ }^{27}$ Indeed, at the international level, there is a relatively broad consensus over the minimum standards that should be observed in EBs' design to ensure that they are responsive to most of the common discrimination challenges.

This section re-evaluates and synthetises international EBs' standards, placing emphasis on those dimensions that are crucial to achieving better EBs. These standards are used to build a 'Responsiveness Framework' that classifies 'responsiveness dimensions' into three groups, depending on whether they are relevant for 'bottom responsiveness', 'top responsiveness' or both ('general responsiveness'). Each dimension includes several subdimensions summarised in Table 1 and discussed in detail in the remainder of this section.

\footnotetext{
${ }^{24}$ FRA (2012, pp. 19-20); ENAR (2018, p. 4).

${ }^{25}$ FRA (2010, p. 9; 2017).

${ }^{26}$ Busby and McDermont (2012); see generally FRA (2012, pp. 49-60). See further on these challenges in Britain: Renton (2015), Aston, Hill and Tackey (2006), Busby and McDermont (2012); and in Spain: SAV (2016); García Añón and Ruiz Sanz (2013); Ramírez and Chinchón Álvarez (2007).

${ }^{27}$ See also RED, Recital 24; Recommendation, at 30; MacEwen (1997, pp. 236-237); Tyson (2001, p. 216); Holtmaat (2006); Ambrus (2012, p. 317); Ammer et al. (2010, pp. 46-47); Crowley (2016); Van Ballegooij and Moxom (2018).
} 
The key sources considered to build this framework are benchmark documents issued by international bodies or agencies (i.e. the European Commission against Racism and Intolerance (ECRI), the Council of Europe Commissioner for Human Rights (CoE Commissioner), the UN, the EU Fundamental Rights Agency (FRA)) and by umbrella organisations representing EBs (i.e. Equinet). ${ }^{28}$

\subsection{General responsiveness}

At the general level, it is necessary that EBs are able to act independently (Table 1 and section 2.1.1) and that they have enough resources to meaningfully carry out all their functions (Table 1 and section 2.1.2). Quite understandably, these two subdimensions will affect their performance at all levels, including their ability to empower and provide comprehensive assistance to individuals who feel discriminated against.

\subsubsection{Independence}

International instruments strongly emphasise the need for EBs to be independent. The concept of 'independence' is, however, fairly vague and lends itself to different interpretations. ${ }^{29}$ To keep this framework relatively simple, all possible meanings of 'independence' have been included in just two dimensions, namely de jure and de facto independence (ECRI, 2018a, para. 2; CoE Commissioner, 2011, pp. 1415). De jure independence demands that EBs' governing bodies are appointed by and are accountable to the legislative and that appointment procedures are clear and ensure a diverse representation of (civil) society (Paris Principles, p. 1). ${ }^{30}$ De jure independence also entails that appointments should be for a predetermined term and mandate (Paris Principles, p. 3); and appointees should enjoy 'functional immunity' to avoid coercion and 'arbitrary dismissal' (Paris Principles, p. 3; ECRI, 2018a, para. 24). On the other hand, de facto independence can only be guaranteed if EBs have powers to set their own priorities within their mandate and are able to manage their own resources, including their personnel. It is also crucial that they are not under the influence of the state or other external pressures. ${ }^{31}$ If these benchmarks are met, EBs will be more likely to provide assistance freely ${ }^{32}$ and to respond to changing social needs by adjusting the resources allocated to different services.

\subsubsection{Resources}

Additionally, EBs need a certain level of resources to support at least a 'critical mass' of complainants along the full access to justice pathway (CoE Commissioner, 2011). Resources' availability will vary from country to country ${ }^{33}$ and the levels needed will depend on variables like the breadth of the EBs' mandate, the size of vulnerable groups, the levels of discrimination and the roles of other stakeholders. It is imperative, however, that EBs are allocated enough - human, technical and financial resources to effectively perform all their functions (ECRI, 2018a; Equinet, 2016, p. 5) ${ }^{34}$ and that they are protected against arbitrary or disproportionate budget reductions or against extensions of their mandates without a paralleled increase in resources (ECRI, 2018a).

\footnotetext{
${ }^{28} \mathrm{~A}$ few landmark comparative reports focusing on European EBs are also considered, namely Holtmaat (2006); Ammer et al. (2010); Crowley and Gaspard (2018).

${ }^{29}$ Yesilkagit and Snijders (2008, pp. 14-15) identify up to six different types of independence; see also Holtmaat (2006, p. 32).

${ }^{30}$ UNGA, 'Res 48/134 on National institutions for the promotion and protection of human rights' (1993) UN doc A/RES/ $48 / 134$.

${ }^{31}$ In this sense, EBs must be independent not only from the state, but also from other actors, such as interest groups and even NGOs, which may often be fundamental partners for EBs but can also challenge their impartiality; see further Yesilkagit and Snijders (2008, pp. 36-37).

${ }^{32}$ Even if a potential complaint is against a central or local government body; see further MacEwen (1997, p. 7).

${ }^{33}$ E.g. depending on the gross domestic product, demographics or economic outlook; see further Holtmaat (2006, pp. 46-47).

${ }^{34}$ As argued by Yesilkagit and Snijders (2008, p. 23): '[f]inancial resources are what blood is to the body.'
} 


\subsection{Bottom responsiveness}

Building on their independence and resource levels, EBs should offer a wide range of support services to alleged victims (Table 1,2.B), particularly legal assistance and legal advice. Additionally, in contexts with high levels of underreporting, EBs' accessibility will also be necessary (Table 1, 2.A) for good bottom responsiveness (CoE Commissioner, 2011, p. 17). ${ }^{35}$

\subsubsection{Accessibility}

Accessibility includes at least two aspects. First, it is imperative that, through awareness-raising initiatives and outreach campaigns (Table 1,2.A.i), EBs are 'present' with the most disenfranchised groups and that they build 'sustained links' with them (ECRI, 2018a). This can improve the understanding of what amounts to discrimination, contribute to build reciprocal trust and raise awareness about antidiscrimination rights and enforcement procedures. Furthermore, outreach work enhances the visibility of EBs and may empower individuals experiencing discrimination to take cases forward ( $\mathrm{CoE}$ Commissioner, 2011, pp. 7, 17-18).

Second, accessibility requires lessening external barriers to access EBs' services (Table 1, 2.A.ii), namely providing assistance through a wide range of channels, including online, e-mail, telephone and face-to-face options (ECRI, 2018a, para. 40). Ensuring that the location is easily accessible may entail 'bridg[ing] physical distance to first contact points' (FRA, 2012, p. 7) through the setting-up of local and/or regional premises (ECRI, 1997; 2018a; CoE Commissioner, 2011, pp. 17-18). Good accessibility equally requires adjusting services for diverse potential users ${ }^{36}$ and providing a confidential and free-of-charge service ${ }^{37}$ in a language in which the complainant is proficient (ECRI, 2018a, paras 16, 40; CoE Commissioner, 2011, pp. 17-18; Equinet, 2016, p. 6). Ensuring that EBs' personnel is as diverse as possible equally contributes to making a wider range of people feel welcome and to be perceived as accessible (ICHRP, 2005, pp. 16-17).

\subsubsection{Support services for alleged victims}

On its own, accessibility is not enough to ensure that EBs are responsive at the bottom; it is also essential that they support individuals who feel discriminated against (ECRI, 2018a, paras 10, 14). Ideally, EBs should offer a wide range of support services, including not only legal services, but also emotional and/or psychological support (FRA, 2012, p. 51; Table 1, 2.B.i-iv). The ability to do so will clearly depend on various factors (e.g. resources, staff skills), but simply an empathic attitude from support staff can empower individuals to lodge complaints or to overcome stressful adjudication procedures (FRA, 2012, pp. 51-52).

In terms of legal support, there is some terminological confusion over the services that EBs ought to offer. While it seems fairly clear that providing 'legal assistance' or 'legal advice' is different from hearing and investigating complaints, ${ }^{38}$ the distinction between the expressions 'legal assistance' and 'legal advice' is more intricate, as they are used with different - yet sometimes overlapping - meanings. In fact, different EBs have interpreted these expressions in various ways. ${ }^{39}$ Building on common-law concepts, ${ }^{40}$ in this paper, 'legal assistance' refers to helping individuals exposed to discrimination by

\footnotetext{
${ }^{35}$ See also ECRI (1997, Principle 6); IHRCP (2005, paras 7, 16); Ammer et al. (2010); Crowley (2016).

${ }^{36}$ E.g. the disabled, religious or ethnic minorities, individuals with tight schedules or care responsibilities, who may not be able to access the service during standard office hours; see FRA (2012, pp. 56-57).

${ }^{37}$ The cost-free element is crucial: 'The biggest barrier of all is the lack of good legal advice at a price that the man in the street can afford to pay' (FRA, 2012, p. 49).

${ }^{38}$ See e.g. ECRI (2018a, para. 17); Holtmaat (2006, p. 24).

${ }^{39}$ See examples in Holtmaat (2007, Parts I, III).

${ }^{40}$ Rhode (1990). Similarly, the Oxford English Dictionary (2018) defines 'assistance' as the action of helping someone through the provision of money, resources or information, whereas 'legal advice' is defined as 'professional advice provided by a lawyer'. I thank Michael O’Neill (Irish Human Rights and Equality Commission) for useful insights on this distinction.
} 
providing them with general information about the substantive and/or procedural aspects of the law ${ }^{41}$; this can be done by anyone with sufficient knowledge. Quite differently, providing 'legal advice' to someone requires the application of the law to a specific factual situation, traditionally by trained lawyers, ${ }^{42}$ offering 'professional judgment' on the best course of action and acting on behalf of the client, if required (ABA, 2002, Rule 2.1). This distinction has been impliedly recognised by both the ECRI (2018a, para. 14a) and the CoE Commissioner (2011, p. 13). Indeed, the latter and most international bodies recommend that EBs provide both 'legal assistance' and 'legal advice'. For instance, the ECRI (1997) suggests that the 'support and litigation function' of EBs should include, inter alia, providing 'personal support and assistance ... to secure [complainants] rights' before the relevant institutions, representing complainants in legal or administrative proceedings and bringing cases in its own name (para. 10(a), emphasis added).

On the whole, therefore, responsive EBs should offer not only general support and legal assistance stricto senso, but also legal advice and, in strategic cases, they should also be able to initiate claims in their own name and to represent claimants before adjudicatory bodies so that the latter can 'navigate and be supported along the full pathway for access to justice' (Equinet, 2016, p. 5).

\subsection{Top responsiveness}

To effectively address discrimination general and bottom responsiveness is not enough. Discrimination is often the product of collective social forces, so EBs should also be equipped to take action at systemic level (Table 1, 3.A). To effectively do so, they should also co-ordinate their actions with other stakeholders (Table 1, 3.B).

\subsubsection{Systemic action}

As MacEwen (1997, p. 10) points out: '[u]nless [antidiscrimination laws] are accompanied by government policies and strategies which imbed the legislative provisions in a more holistic approach to discrimination, substantial change is unlikely to be effective.' Indeed, aside from reactively supporting alleged victims, responsive EBs must have powers to promote equality and prevent discrimination.

EBs' systemic action can include a diverse range of powers, but they may broadly be grouped around three clusters. First, they need to have powers to collect information to identify key issues to be addressed at the grass-roots level, such as to conduct inquiries and research 'on their own initiative into all matters falling under their mandate', both as regards individual and structural discrimination (ECRI, 2018a, para. 13.c-d; CoE Commissioner, 2011, p. 6). Their contact with people exposed to discrimination, either directly - through their support services ${ }^{43}$ - or indirectly - through dialogue with non-governmental organisations (NGOs) and other organisations ${ }^{44}$ - can also be a valuable source of information (ECRI, 2018a, para. 13.b).

Second, EBs must be able to act on the issues identified thanks to the information gathered. At this stage, promotion action may range from launching campaigns to build awareness about antidiscrimination legislation and 'a culture of compliance' among employers, service providers and policy-makers (ECRI, 2018a, para. 13.e; CoE Commissioner, 2011, p. 6; Equinet, 2016, p. 4) to promoting good

\footnotetext{
${ }^{41}$ E.g. 'providing information about the existence of anti-discrimination legislation ... and about the possibility of taking legal action against discrimination, referring the victim to an organisation/institution that could assist with formulating an official complaint, or helping the victim and the (alleged) perpetrator come to an amicable settlement (mediation)' (Holtmaat, 2006, p. 24).

${ }^{42}$ But Rhode (1990) argues that legal advice should also be provided by lay advisers with relevant expertise.

${ }^{43}$ As MacEwen (1997, pp. 239-240) illustrates with examples from the former British 'Commission for Racial Equality' (CRE), making the 'linkage' between support services to victims and the promotion powers can provide 'reference points, relevancy and weight' to promotion policies. For instance, the CRE launched promotion campaigns in the field of housing discrimination that were informed by both individual cases and its own investigations.

${ }^{44}$ See section 2.3.2.
} 
practices and positive action measures to address systemic discrimination, in both the public and private sectors (ECRI, 2018a, para. 13.e-f; CoE Commissioner, 2011, p. 13; Equinet, 2016, p. 4).

Finally, the two subdimensions just discussed should be complemented by an 'advisory' function, ${ }^{45}$ so that EBs can use their expert knowledge to directly influence policy and legislation from the top. This should enable EBs to participate in consultation procedures and make recommendations regarding new policies and legislation, among other potential powers (ECRI, 2018a, para. 13.j; CoE Commissioner, 2011, p. 19; Equinet, 2016, p. 4).

\subsubsection{Co-ordination}

The co-ordination of EBs' strategies and activities with other stakeholders can also be decisive to improve their responsiveness. In most jurisdictions, there will be an array of entities directly or indirectly involved in equality promotion and/or support to complainants, such as public institutions (e.g. Ombudsmen, Labour Inspectorates, Consumer Defence Bodies), employers' associations, trade unions, NGOs and informal groups representing vulnerable communities (ECRI, 2018a, paras 13.b, 21; CoE Commissioner, 2011, p. 20). Co-ordination between EBs and these institutions is crucial to build a shared understanding of key issues to be addressed and create synergies, avoid duplication of activities and maximise impact. ${ }^{46}$ EBs can even become 'equality hubs' leading networking efforts and helping to optimise the use of resources to achieve the common aspiration of promoting equality (CoE Commissioner, 2011, pp. 12, 18; Equinet, 2016, pp. 4, 16). Being in close contact with NGOs representing vulnerable groups can contribute to better educating the latter about their rights and enforcement pathways, to build reciprocal trust and to empower individuals to recognise discrimination and act against it, ${ }^{47}$ thus fostering the autonomy of groups exposed to discrimination.

These top-level activities can also contribute to addressing discrimination at the bottom, and vice versa. For instance, at the bottom, EBs should support individual victims not only to address underreporting and challenge discrimination, but also to gain intelligence that can inform EBs' activities at the top level (e.g. to approach employers to change systemic discriminatory policies, undertake strategic litigation or run awareness-raising campaigns in collaboration with other stakeholders). Thus, the three responsiveness levels are interrelated. Building on these principles, section 3 demonstrates how the vague provisions of the RED are likely to undermine EBs' responsiveness.

\section{The door left opened to unresponsive designs: the gaps of the RED}

The crucial influence that EU 2000s' Directives have had in the development of EBs across the EU should not be downplayed. ${ }^{48}$ Despite some implementation and compliance problems, the Directives were the main driver for the setting-up of most of the EBs that are now place in MS (Van Ballegooij and Moxom, 2018). Yet, their limits must also be acknowledged. This section analyses the rather elusive provisions of the RED to identify their gaps in relation to the Responsiveness Framework.

The RED itself clearly recognises the potential of EBs to respond to discrimination. Indeed, Recital 24 of the Directive states that

'[p]rotection against discrimination based on racial or ethnic origin would itself be strengthened by the existence of a body or bodies in each Member State, with competence to analyse the problems involved, to study possible solutions [top responsiveness] and to provide concrete assistance for the victims [bottom responsiveness].' (Emphasis added)

\footnotetext{
${ }^{45}$ This terminology is borrowed from Crowley (2018).

${ }^{46}$ However, EBs should strive to preserve their impartiality and independence (CoE Commissioner, 2011, p. 18; Yesilkagit and Snijders, 2008).

${ }^{47}$ Some existing benchmarks indirectly support this claim (e.g. ECRI, 2018a, para. 13; CoE Commissioner, 2011, pp. 18, 21).

${ }^{48}$ See further Benedi Lahuerta (forthcoming in 2022).
} 
The EU Commission (2018) has also stressed that ' $\mathrm{t}$ ] he best way to effectively implement and enforce [EU antidiscrimination legislation] is through the use of independent equality bodies'.

However, the RED equally notes that it only 'lays down minimum standards', ${ }^{49}$ which leaves plenty of freedom at the implementation stage - so much so that MS may set up EBs in full compliance with the Directive by designing largely unresponsive EBs. This can be appreciated by applying the 'Responsiveness Framework' to the RED provisions.

First, the two key dimensions contributing to the general EBs' responsiveness are being independent and having enough resources. The first striking feature of the RED is that it does not require that EBs are formally (de jure) independent. For instance, the Directive does not demand that national EBs are self-standing and/or have legal personality. ${ }^{50}$ Accordingly, EBs may be embedded within national human rights' institutions, or even within government departments. ${ }^{51}$ The former is not necessarily a problem provided that the human rights institution enjoys formal independence, ${ }^{52}$ but belonging to a government department can hinder a given EB's potential to use its powers and resources as it sees fit. On the other hand, the RED establishes that EBs should perform their assistance and advisory functions ${ }^{53}$ independently in practice (de facto). ${ }^{54}$ This should lead to implementation designs that ensure that EBs undertake each of these functions in an independent manner. Yet, the lack of a formal independence requirement entails that EBs may lack organic and/or financial independence to take key decisions on their own, such as adopting its strategic plan or shifting resources between different areas. ${ }^{55}$ This loophole is likely to undermine the responsiveness of EBs, unless national EBs' designs go beyond the minimum RED standards.

Regarding the level of resources, the RED simply indicates that these functions may be performed by one or more bodies, or even by national human rights institutions, ${ }^{56}$ without any reference to the need to allocate sufficient resources to EBs according to their size and powers, or to the need to protect these bodies against arbitrary budgetary reductions. Indeed, various surveys have found that the lack of staff and financial resources is one the most pressing challenges faced by EBs (Figure 1) ${ }^{57}$ and the 'most significant barrier' to being effective and 'realis[ing] their full potential' (Crowley, 2018, p. 103).

Second, at the bottom-responsiveness level, the RED does not lay any clear standard regarding accessibility. In terms of awareness-raising, the Directive only includes a general reference to the need to disseminate information about antidiscrimination legislation so that it is brought to the attention of the persons concerned by all appropriate means throughout their territory. ${ }^{58}$ It could be argued that, as key players in equality promotion and the fighting of discrimination, EBs should be one of the 'means' used to disseminate that information through regular contact with vulnerable groups and outreach campaigns. Nevertheless, once again, the RED does not formally require so, and it does not demand either that external barriers to access EBs' services are minimised. ${ }^{59}$ Recent surveys confirm that these gaps have led to practical problems at the national level, such as the lack of awareness of EBs and/or antidiscrimination legislation (FRA, 2017) and the overwhelming lack of local or regional offices. ${ }^{60}$

\footnotetext{
${ }^{49}$ Recital 25, Art. 6.

${ }^{50}$ E.g. Art. 13(1) RED allows that EBs 'form part of agencies charged at national level with the defence of human rights or the safeguard of individuals' rights'.

${ }^{51}$ This is currently the case for ten EBs (Crowley, 2018, p. 90).

${ }^{52}$ See further discussion on the (dis)advantages of this institutional design in Crowther and O'Cinneide (2019).

${ }^{53}$ I.e. conducting surveys, publishing reports and making recommendations (Art. 13(2) RED).

${ }^{54}$ Ibid.

${ }^{55}$ These types of interferences have been found e.g. in Portugal, Greece (Ammer et al., 2010, p. 111), Finland, Italy and Sweden (Crowley, 2018, Table 6).

${ }^{56}$ Ibid.; see also e.g. De Witte (2011).

${ }^{57}$ This problem worsened with the 2008 financial crisis; see e.g. Ammer et al. (2010, pp. 78, 140-142); Givens and Case (2014, chapter 7); Equinet (2012).

${ }^{58}$ Art. 10 RED, emphasis added.

${ }^{59}$ See, however, a timid reference to lessening financial barriers to access EBs' assistance in Directive 2014/113/EC, which establishes that the latter should be 'free of charge to persons who lack sufficient resources', Art. 4(2), emphasis added.

${ }^{60}$ Only available in ten of the countries surveyed by Crowley $(2018$, p. 118).
} 


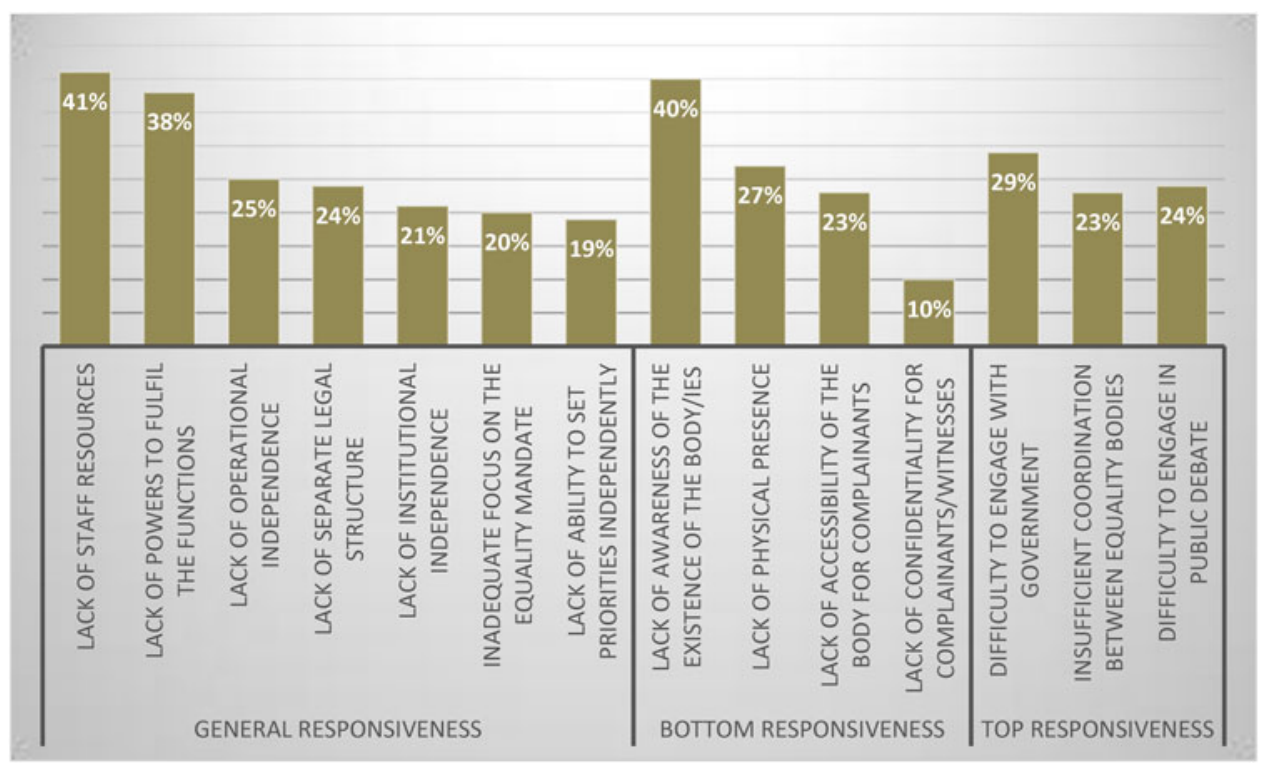

Figure 1. Challenges faced by EBs at the national level.

Source: Adapted from EU Commission (Targeted Consultation 2018).

Note: The consultation scale had five possible answers, from which respondents had to choose one. For simplicity, 'considerable challenge', 'challenge' and 'somewhat a challenge' have been grouped under 'challenge'; 'not a challenge' and 'no opinion' have been omitted.

The RED is also very vague regarding another subdimension of bottom responsiveness, namely the type/s of support service/s that EBs should offer to individuals who feel discriminated against. The Directive simply establishes that EBs should 'provid[e] independent assistance to victims of discrimination in pursuing their complaints about discrimination', without any guidance as to what is meant by 'assistance' or how it should be provided. ${ }^{61}$ This wording gives MS plenty of room to decide on these issues as they see fit. ${ }^{62}$ Still, following a purposive interpretation of the RED's preamble (demanding that EBs provide 'concrete' and 'practical' assistance to victims) ${ }^{63}$ and of the requirement to assist victims 'in pursuing their complaints about discrimination', it may be argued that EBs' support services should help individuals to enforce their antidiscrimination rights in their specific case. Accordingly, having only a website with general information about how to get redress could be considered insufficient to meet the RED minimum standards. It seems, therefore, that EBs should provide, at least, legal assistance. ${ }^{64}$ However, the vague wording of the RED and its preparatory works ${ }^{65}$ would probably not support interpreting 'assistance' as including legal advice or legal representation (Tyson, 2001; Jacobsen, 2010, pp. 88-89).

Third, if we turn our attention to the top-responsiveness dimensions, the RED includes some references to aspects relevant to taking systemic action against discrimination. Article 13(2) requires that EBs have powers to '[conduct] independent surveys concerning discrimination' and to '[publish] independent reports and [make recommendations] on any issue relating to such discrimination', but leaves the terms 'surveys', 'reports' and 'recommendations' open for interpretation. ${ }^{66}$ For instance, it is

\footnotetext{
${ }^{61}$ Similarly, see Barry (2003, p. 418).

${ }^{62}$ See Holtmaat (2006) for examples of diverging interpretations. Whilst various surveys compare EBs' support powers (e.g. Ammer et al., 2010; Crowley, 2018), it is difficult to assess the actual services provided because they rely on different definitions of 'assistance' that do not necessarily match the definition used in this paper.

${ }^{63}$ Recital 24. See also Directive 2004/113/EC, Recital 25; Directive 2010/41/EU, Recital 22, emphases added.

${ }^{64}$ Similarly, see Equinet (2010, p. 11).

${ }^{65}$ On the preparatory works, see further Tyson (2001); Ambrus (2012, pp. 334-335); Jacobsen (2010, pp. 81-85).

${ }^{66}$ See examples of national interpretations of these terms in Holtmaat (2006); Crowley (2018).
} 
unclear whether conducting surveys demands that EBs have investigatory powers to collect relevant data $^{67}$ and whether the EBs should have powers to issue 'recommendations' at their own initiative or only upon the request of a governmental or legislative body.

Finally, regarding the co-ordination dimension, once again, the RED broadly encourages social dialogue (Art. 11) and dialogue with NGOs (Art. 12). Whilst EBs could be involved in the effective implementation of these articles, and would be particularly well placed to 'encourage dialogue with appropriate non-governmental organisations which have ... a legitimate interest in contributing to the fight against discrimination', ${ }^{68}$ the actual wording of these two articles does not require that EBs partake in or encourage these dialogues.

Various EU publications and grey literature studies attest how the vague RED standards have led to an exceptional diversity of interpretations and different implementation approaches across MS. ${ }^{69}$ For example, the results of a 2018 targeted consultation show that the loopholes discussed supra have created various challenges for EBs, including the lack of staff resources, the lack of awareness of the existence of EBs and the lack of physical presence (see Figure 1).

Indeed, the 2018 Recommendation acknowledges these gaps and the consequent challenges, ${ }^{70}$ and generally recognises that

' $[\mathrm{t}]$ he text of the equality Directives leaves a wide margin of discretion to Member States on the structure and functioning of equality bodies. This results in significant differences ... [and] sometimes leads to unsatisfactory access to protection for citizens, a protection which is unequal from one Member State to another. ${ }^{, 71}$

The next section delves deeply into two examples of national implementation to demonstrate how the broad margin of manoeuvre left by the RED has led to largely divergent implementation approaches and to designing EBs that are unresponsive at the bottom and/or at the top.

\section{Comparing the British and Spanish EBs: unresponsive, with or without resources}

This section compares the British Equality and Human Rights Commission (EHRC) and the Spanish Consejo para la Eliminación de la Discriminación Racial o Étnica (CERED) against each other and against the 'Responsiveness Framework. ${ }^{72}$ Through this comparative exercise, it becomes evident that both promotion-type bodies face contrasting challenges to respond to discrimination due to their different institutional designs.

To start with, their origin and competences are fairly different. The EHRC is a multi-ground body with powers regarding all grounds protected under the Equality Act $2010^{73}$ and in the broader field of human rights. ${ }^{74}$ On the other hand, the CERED is a single-ground equality body that only has powers in the field of race or ethnic discrimination. ${ }^{75}$ Furthermore, whilst the EHRC was only set up in 2006,

\footnotetext{
${ }^{67}$ See Bell (2001, p. 48); Ambrus (2012, p. 343).

${ }^{68}$ Art. 12 RED.

${ }^{69}$ E.g. Holtmaat (2006); Ammer et al. (2010); Crowley (2018).

${ }^{70}$ Recommendation, at $18-26$.

${ }^{71}$ Ibid., at 18 (see also note 7 above).

${ }^{72}$ Section 2.

${ }^{73}$ Namely age, disability, race, sex, sexual orientation, pregnancy and maternity, gender reassignment and marriage or civil partnership.

${ }^{74}$ It is the National Human Rights Institution (NHRI) for the purposes of the UN.

${ }^{75}$ The fact that the CERED is a single-ground body is likely to hinder action against intersectional discrimination. Conversely, the EHRC's multi-ground mandate allows a better intersectional approach, although it is not a guarantee that it will work in practice (Verloo et al., 2012, p. 531). In fact, Cohen (Interview, 6 December 2012; see Appendix) considers that, at least in its early years, the EHRC worked in silos rather than as a multi-ground body.
} 
it partly builds on the expertise of its three predecessors. ${ }^{76}$ Conversely, the CERED was established in 2010 in view of implementing the RED, so it is a 'younger' institution. Despite these differences, both are the designated 'bodies for the promotion of equal treatment' for the purposes of the $\mathrm{RED}^{77}$ and should seek to be as responsive as possible to discrimination.

\subsection{General responsiveness}

As discussed supra, two general prerequisites that support EBs' responsiveness are their independence and the level of resources available to perform their tasks (Table 1, 1.A and 1.B). Whilst neither the EHRC nor the CERED can be considered to enjoy full de jure independence given that they are both attached to a government department, ${ }^{78}$ the EHRC's legal configuration safeguards de jure independence better than the CERED's set-up. ${ }^{79}$ Indeed, the EHRC is an 'independent arm's length body ${ }^{80}$ and a body corporate (Equality Act (EqA) 2006, s. 1) with legal personality and its own rights and responsibilities. In contrast, the CERED is a collegiate body embedded in a government ministry and lacks legal personality. Furthermore, the EHRC lays its strategic plan and accounts before parliament (DCMS and EHRC, 2015, paras $8.3,11.1,14.1$ ) and is governed by a Chair and a board of Commissioners deemed to be independent from the government. ${ }^{81}$ In contrast, 44 per cent of the CERED plenary members are directly appointed by government (or collegiate bodies under the latter's control). ${ }^{82}$

In practice, however, neither the EHRC nor the CERED enjoys full de facto independence. The CERED does not have its own staff ${ }^{83}$ and its budget is part of that same ministry. ${ }^{84}$ Accordingly, even though it is for the CERED's plenum to establish its line of action, ${ }^{85}$ the lack of its own resources poses great difficulties in doing so. Whilst the EHRC's budget is also determined by its sponsor government department, ${ }^{86}$ the former has responsibility for the recruitment of its own staff (EqA 2006, Sch. 1, para. 7(3); DCMS and EHRC, 2015, para. 15.1) ${ }^{87}$ and can set its own priorities through its three-year strategic plan (DCMS and EHRC, 2015, para. 7.1). However, the practical relevance of these powers is hampered by its financial dependence on the Government Equalities' Office (GEO), which approves its spending 'in relation to value for money only and not whether the EHRC should undertake the activity in line with its statutory powers and duties' (DCMS and EHRC, 2015, para. 6, emphasis added).

Besides independence, responsive EBs must also have sufficient resources to perform all their tasks. The case-study EBs have very different resource levels: whereas, for the last three years, the EHRC's budget has been in the range of $£ 22-23$ million, the CERED's budget has always been under $€ 700,000 .{ }^{88}$ However, Britain has a larger population than Spain ${ }^{89}$ and, as noted supra, the EHRC's

\footnotetext{
${ }^{76}$ Namely the CRE, the Equal Opportunities Commission (EOC) and the Disability Rights Commission (DRC); see EqA 2006. This transformation was strongly criticised by some, e.g. Cohen (Interview, 6 December 2012; see Appendix); more generally see O’Cinneide (2007); Hepple (2012, p. 146).

${ }^{77}$ Art. 13 RED.

${ }^{78}$ The EHRC is attached to the Government Equalities' Office (GEO), whereas the CERED is attached to the Presidency Ministry and to the Instituto de la Mujer y para la Igualdad de Oportunidades (Ley 15/2014, Arts 17-18).

${ }^{79}$ Unlike the EHRC, the ECRI has required greater independence safeguards for the CERED (ECRI, 2010, paras 68-73; 2011, paras 28-37).

${ }^{80}$ EHRC, 'Governance', available at www.equalityhumanrights.com/about-us/governance/ (accessed 9 January 2014).

${ }^{81}$ The Chair and the Commissioners are appointed through an open competition based on knowledge, experience, suitability and desirability (House of Lords \& House of Commons, JCHR, 2009-2010, Evidence 78-79). Recent appointments have been controversial; see Siddique (2020).

${ }^{82}$ RD 1262/2007, Art. 4; Orden TAS/113/2008; Orden SSI/2602/2012.

${ }^{83}$ It borrows around five civil servants from the ministry that it belongs to, who work part-time on the CERED's tasks and are supported by a full-time external adviser (Equinet, 2018).

${ }^{84} \mathrm{RD} 1262 / 2007$, Disposición Adicional 3a, as amended by RD 1044/2009, Art. 1(6).

${ }^{85}$ Ibid., Art. 12.5.a.

${ }^{86}$ Currently, the Home Office (EHRC, 2018, p. 17).

${ }^{87}$ In 2017, it had 172 staff members (Crowley, 2018, p. 116).

${ }^{88} € 0.52$ million in 2017 (ibid., p. 115).

${ }^{89} 64.2$ and 46.5 million inhabitants in 2017, respectively (ONS, 2018; INE, 2017).
} 

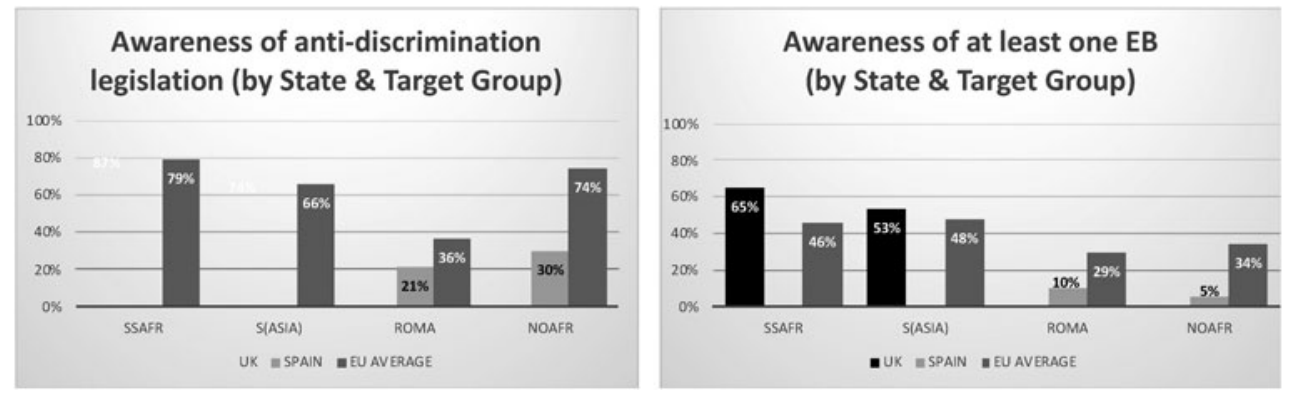

Figure 2. Awareness of antidiscrimination legislation and Equality Bodies in the UK, Spain and the EU. Source: Adapted from FRA (EU Midis II, 2017)

mandate is also much larger than that of the CERED. For these reasons, a strict comparison of their resources is not advisable. However, it broadly seems that the larger financial resources of the EHRC could put this institution in a more advantageous position to perform its functions more effectively than for the CERED, and hence to be more responsive. ${ }^{90}$

\subsection{Bottom responsiveness}

To assess the CERED's and the EHRC's bottom responsiveness, it is necessary to briefly introduce their general approach to support alleged victims of discrimination. Despite the CERED's lack of independence and modest resources, it has managed to establish a 'low-cost' support system based on a Network of Assistance (Servicio de Asistencia a Víctimas de Discriminación Racial y Étnica, hereinafter 'SAV' or 'the Network') formed by eight NGOs working in the field of racial discrimination, ${ }^{91}$ including the co-ordinating one, Fundación Secretariado Gitano (FSG). ${ }^{92}$ Unlike the CERED, the EHRC does not provide direct support to alleged victims anymore. ${ }^{93}$ The latter's helpline, which provided legal assistance to complainants (EHRC, 2009), was externalised in 2012 under the label 'Equality Advisory Support Service’ (EASS) due, mainly, to cost-effectiveness reasons (GEO, 2011, pp. 73-82). Therefore, the EHRC only currently engages in selected strategic litigation cases.

This brief overview of the CERED and the EHRC support services suffices to assess their performance against the accessibility dimension (Table 1,2.A). As discussed earlier, to maximise accessibility, EBs should raise awareness about antidiscrimination rights, enforcement procedures and their support services. However, the efforts required may vary from country to country. For instance, the EHRC may have benefited from visibility campaigns undertaken in the 1990s by the former Commission for Racial Equality $(\mathrm{CRE})^{94}$ so, in a recent survey, 60 per cent of UK respondents were aware of at least one EB, whereas only 6 per cent of Spanish respondents were (FRA, 2017, p. 52). Awareness of EBs may in turn influence vulnerable groups' awareness about antidiscrimination legislation, which, in the $\mathrm{UK}$, is among the highest in the EU, whereas, in Spain, it is among the lowest (see Figure 2).

Indeed, the CERED has recognised that important efforts are still needed to improve its visibility and awareness about the services it provides (SAV, 2016, p. 71). Its Network has been trying to address this through active dissemination campaigns, such as by launching a new website, distributing more than 20,500 leaflets and holding more than 150 information events. Nevertheless, what seems more

\footnotetext{
${ }^{90}$ In fact, the EHRC's budget is one of the largest across the EU (Crowley, 2018, Table 7).

${ }^{91}$ The NGOs involved work in the areas of Roma inclusion, migrant and refugee support, human rights, and social and humanitarian aid; see further SAV (2016, pp. 6-10).

${ }^{92}$ By subcontracting these services, the CERED arguably complies with the benchmark of 'independent' assistance despite its institutional dependence on government.

${ }^{93}$ Instead, the EHRC has a 'Lawyers' Referral Helpline' that legal advisers can use to make referrals about cases suitable for strategic litigation and an 'Advisor Support telephone helpline' (EHRC, 2018, p. 21).

${ }^{94}$ E.g. the 'Uniting Britain for a Just Society' advertising campaign; see Boothman and MacEwen (1997, p. 170).
} 
effective is the Network NGOs' ability to reach out to vulnerable groups through their own programmes. For example, the Spanish Red Cross has schemes to promote migrants' employability and FSG has a successful programme focusing on Roma employability (Acceder) (FSG, 2011). Through these activities, these organisations are constantly in touch with vulnerable communities, so they are able to spot discrimination, even when victims have not recognised it (Belsué interview, 18 April 2013; Pulido interview, 20 April 2013; see Appendix). Giménez (Interview, 23 April 2013; see Appendix), from FSG, explains:

'[identifying discrimination] comes naturally .... When someone is trying to find a job, my colleagues easily realise when the candidate is not invited to an interview for racial reasons; or how it turns out that "the position has been filled" when the candidate is invited [to an interview] and the employer sees his physical appearance. My colleagues often phone the company afterwards and they are told that the position is still available.'

This close contact contributes to reducing underreporting and lumping, and to addressing discrimination promptly. Anecdotal evidence shows that it can even help to eradicate systemic discrimination through positive role models (Giménez interview, 23 April 2013; see Appendix). For example, a Roma woman was rejected for a job at a bakery because the manager believed that 'Roma don't know how to work'. Yet, she was eventually hired - and even promoted - thanks to FSG mediation (FSG, 2011, p. 35).

Whereas, in Britain, there is higher awareness of the EHRC, the latter does not have a direct interface with complainants, so 'people don't see the EHRC as a body which can help them, but rather as a body which is there on behalf of the Government' (Sullivan interview, 29 March 2013; see Appendix). ${ }^{95}$ Instead, the EASS provides the vast amount of discrimination assistance. Yet, awareness of the latter varies greatly by geographical areas: while there is a 'healthy awareness' about the EASS services in London and the south-east of England, 'more work can be done [to improve awareness] in north-east England, Scotland and Wales' (EASS, 2017). ${ }^{96}$ However, neither the EHRC nor the EASS seems to be actively engaging with vulnerable communities to address this, and it is doubtful that the mere existence of the EHRC and EASS websites will draw the attention of the more marginalised individuals, who may not even have access to smartphones or computers. ${ }^{97}$

Accessibility can also be greatly enhanced by minimising barriers to accessing support services. Both the CERED and the EASS (and, to a limited extent, the EHRC) comply with the basic requirements of providing cost-free, confidential and multilingual assistance ${ }^{98}$ through a range of channels, including a general-information website, a webform, an e-mail address and a telephone helpline. ${ }^{99}$ However, a key difference between the assistance channels in Britain and those in Spain is that, unlike the EHRC and the EASS, the CERED has managed to offer face-to-face assistance with wide geographical coverage. The SAV has country-wide presence, with eighty-seven access points and at least one branch in each Autonomous Region (SAV, 2012, pp. 2-3, 6-11), ${ }^{100}$ and its advisers often belong to vulnerable communities, which helps to build trust with complainants. ${ }^{101}$

\footnotetext{
${ }^{95}$ This contrasts with the former CRE, which had regional offices (Boothman and MacEwen, 1997, pp. 162-163; Cohen interview, 6 December 2012; see Appendix).

${ }^{96}$ Between October 2016 and January 2017, more than 32 per cent of the telephone calls it received originated in London and the south-east of England (EASS, 2017).

${ }^{97}$ See e.g. Parraudin (2018).

${ }^{98}$ Most sections of the EASS website are available in Welsh and the helpline provides assistance in other languages; the CERED Network's website is available in English, Catalan, Basque and Galician; it also contains leaflets in English, French, Chinese, Arab and Romanian.

${ }^{99}$ The EASS also offers assistance by text message and post.

${ }^{100}$ To ensure that common minimum standards are met across its access points, the Network has a protocol and advisers who are trained in discrimination assistance (SAV, 2012, pp. 3-5; 2015, p. 10).

${ }^{101}$ The EHRC reports having a fairly diverse workforce (e.g. 60 per cent are females, 14 per cent have a disability and 12 per cent belong to an ethnic minority; EHRC, 2019, p. 11) but this has limited practical relevance given its lack of direct interface with the public.
} 
It could be argued that the lack of 'official' face-to-face assistance in Britain is not problematic because telephone and online assistance are available (Widdison, 2003). Yet, it is questionable that these can effectively replace face-to-face assistance. Although combining different access channels can increase the potential to reach disadvantaged groups (Griffith and Burton, 2011, pp. 6-7), substituting face-to-face assistance with remote assistance could have the opposite effect. Concerns have been raised about the use of telephone instead of face-to-face assistance due to the faster pace and lack of visual clues in telephone communications, which may make it more difficult to establish a good interpersonal relationship and decrease the quality of communication (Griffith and Burton, 2011; Balmer et al., 2012) in a context in which victims tend to value familiarity and trust (Buck and Curran, 2009, p. 25). ${ }^{102}$ Indeed, in the Spanish case, while telephone and website assistance are available, victims overwhelmingly prefer face-to-face assistance (SAV, 2015, p. 50).

Having examined the accessibility dimension, the next bottom-responsiveness dimension to be considered are support services for alleged victims (Table 1, 2.B). In Spain, the CERED ensures, through the SAV, that the support services provided are as comprehensive as possible, including guidance on the possible paths to solve the incident, legal assistance and advice, case-work, negotiation and mediation, and, in some cases, psychological counselling (SAV, 2015, p. 42). ${ }^{103}$ However, given that the CERED does not have legal personality, the Network NGOs cannot undertake strategic litigation on behalf of the CERED.

In contrast, the EHRC can get involved in strategic litigation but does not directly support individuals who feel discriminated against. Instead, the body that is deemed to do so is the EASS. However, the latter only provides legal assistance about 'how the equality act works, and how it may be relevant to [the complainant's] situation' (EASS, 2018). This includes helping alleged victims to identify the relevant protected characteristic, the prohibited conduct and the sector in which the incident occurred, as well as assisting them in drafting an action plan to resolve the issue informally - on their own. ${ }^{104}$ Indeed, the EASS tends to 'steer clear of any sort of view on the merits of whether someone has a discrimination complaint that is valid or not, or what they should do about it, which is the bit that people really need' (House of Lords, 2016, p. 149). Accordingly, unlike complainants who contact the CERED Network, the EASS users must be referred to another organisation for legal advice, or they must find a lawyer by themselves. In this transfer process, they may lose interest in pursuing their claims further for various reasons, such as a lack of confidence in the legal system or finding the process too cumbersome for what they get in return:

'When you can only assist victims as regards one part of the process, and, suddenly, they are told that you can only assist them "until here" and that they must be transferred to another service provider to go on with the process, even if you keep in touch with them, in that referral process you lose a lot ... you lose many victims.' (Giménez interview, 23 April 2013; see Appendix) ${ }^{105}$

Another shortcoming of the EASS helpline is that it is run by a generalist company ${ }^{106}$ and, whilst its advisers are trained, the service is far from equivalent to the former EHRC helpline. For instance, it has been criticised for being 'manned by inexperienced staff, keeping a low profile and providing very limited 'advice and support' (House of Lords, 2016, p. 149). In fact, since October 2016, the service has controversially ${ }^{107}$ been run by the company G4S, which has repeatedly been accused of human rights and discriminatory abuses. ${ }^{108}$

\footnotetext{
${ }^{102}$ According to Cohen (Interview, 6 December 2012; see Appendix), the former CRE was more visible and trusted because its regional offices were 'staffed with full time staff from that area' and 'a quite high proportion of the staff were black'.

${ }^{103}$ Ministerio de Sanidad, Servicios Sociales e Igualdad, 'Anuncio de licitación', 2012/21PA001.

${ }^{104}$ The EASS's website (2018) clarifies: ' $\mathrm{t}$ ] he information and support provided by the service is not the same as legal advice.'

${ }^{105}$ This is the well-known phenomenon of 'referral fatigue' (Pleasence et al., 2013, p. 38. see Genn, 1999).

${ }^{106}$ Initially by Sitel, a company specialising in call-centre management.

${ }^{107}$ See e.g. Baroness Deech's speech at HL Deb, 6 September 2016, c964.

${ }^{108}$ See e.g. ibid.; Read (2014); Case C-157/15, Achbita v. G4S Secure Solutions, EU:C:2017:203; Ben-Cnaan (2016).
} 
Overall, neither the EHRC nor the CERED provides all recommended assistance levels. The EASS only provides legal assistance and support to informally settle disputes, whereas the EHRC can only represent a few selected complainants in strategic litigation cases. Whilst the CERED's Network provides comprehensive support, legal assistance and advice, it cannot represent claimants in litigation, which limits its responsiveness at the top. In practice, complainants who reach these 'assistance gaps' will have to be referred to another cost-free provider, will have to seek legal aid or may have to pay a legal practitioner to pursue their claim. Yet, complainants are likely to drop their actions and 'lump it' when they encounter the first assistance gap, which will contribute to higher underreporting rates and lower responsiveness of EBs.

\subsection{Top responsiveness: strategic action and co-ordination as the key enhancers of EBs' role}

As discussed in section 2, at the top, EBs' responsiveness can greatly be enhanced through systemic action and the co-ordination of all antidiscrimination stakeholders. To what extent, then, are the British and Spanish EBs responsive at this level? In both cases, their 'top responsiveness' is limited, albeit for different reasons.

Compared to the CERED, which lacks legal personality and enforcement powers, the EHRC has the 'teeth' to take systemic enforcement action (Table 1, 3.A). ${ }^{109}$ For instance, it collects information through surveys ${ }^{110}$ and it can conduct inquiries regarding any of its duties, which may lead to a report or a recommendation that can be considered by courts (EqA 2006, s. 16(2)(c), Sch. 2, para. 17). The EHRC can also collect information by conducting formal investigations if it has a 'reasonable belief' that someone has committed an 'unlawful act' (EqA 2006, s. 20(2)). To exercise these powers, however, the EHRC must comply with extensive procedural requirements (e.g. providing advance notice or publishing the terms of reference), ${ }^{111}$ which limits their practical relevance. Nevertheless, it has other powers that can be of greater interest to achieve systemic changes: it can enter into voluntary agreements with employers 'in lieu of enforcement' (EqA 2006, s. 23) and initiate court proceedings on its own name to challenge discrimination if there are no identifiable victims or the affected individuals are not able or willing to do so (EqA 2006, s. 30). ${ }^{112}$ In practice, however, the use of these enforcement powers has notably declined since 2009 and there is increasing agreement among experts that the EHRC is not 'feared' by potential defaulting organisations. ${ }^{113}$

Part of the EHRC weakness may be linked to the outsourcing of its helpline in 2012, which has led to not having 'as good flow through of cases and issues as they [had] previously, because there is one more intermediary [the EASS] and they don't have control over it, as they should do' (Allen interview, 15 February 2013; see Appendix). Whilst the EHRC has a Memorandum of Understanding with the EASS, ${ }^{114}$ the externalisation of the helpline has led to a 'sidelining' between the EHRC and certain vulnerable groups and to the EHRC being less able to respond to new discrimination trends (House of Lords, 2016, pp. 146, 148; Women Equalities' Committee (WEC), 2018; HM Government, 2018, pp. 23-24). Furthermore, since the EHRC depends on the EASS to identify cases for strategic litigation (Hewitt interview, 29 March 2013; see Appendix), the referral rate has halved since the helpline was externalised (WEC, 2018, Q88, Q91). ${ }^{115}$ The EHRC has made efforts to improve the information flow with the EASS (House of Lords, 2016, p. 148; WEC, 2018), but it is unlikely that any of these will yield the desired results, for several reasons. For instance, as the EASS depends on the GEO,

\footnotetext{
${ }^{109} \mathrm{~A}$ detailed discussion of those powers is beyond the scope of this contribution; see further Hepple (2014, pp. 177-190).

${ }^{110}$ E.g. the 'How Fair is Britain' and 'Is Britain Fairer' reports, available at https://www.equalityhumanrights.com/en/britain-fairer (accessed 5 March 2021).

${ }^{111}$ EqA 2006, Sch. 2, paras 2, 3, 5.

${ }^{112}$ Relevant individuals would retain their right to take action.

${ }^{113}$ See WEC (2019, pp. 11-15, Table 1).

${ }^{114}$ On that basis, the EHRC gives precise guidelines to the EASS about strategic priorities and trains the EASS advisers to identify strategic cases, which are referred to the EHRC on a monthly basis (WEC, 2018, Q90, Q92, Q97).

${ }^{115}$ In 2016, the EASS received around 2,200 calls per month, only 1.3 per cent of which were referred to the EHRC (House of Lords, 2016, p. 152).
} 
communication is difficult between the EASS and the EHRC, and the latter cannot ask the EASS to perform duties not envisaged in its contract (WEC, 2018, Q88-Q105). Furthermore, the EASS advisers are not lawyers, so they may have more difficulties in identifying strategic cases that could lead to legal developments (WEC, 2018, Q87, Q98-Q99).

Conversely, the CERED Network can identify problems like systemic discrimination thanks to grass-roots assistance based on local NGOs and to networking with other assistance providers. ${ }^{116}$ It is therefore better placed to take strategic action (e.g. issue recommendations). However, unlike the EHRC, the CERED has very limited enforcement powers. It can, inter alia, collect information, publish independent reports at its own initiative or upon request, issue recommendations (including suggestions to amend legislation) and undertake awareness-raising campaigns, ${ }^{117}$ but it lacks legal personality and its own infrastructure. Accordingly, despite having a better connection with social trends, it lacks the independence, resources and powers to actually address the social issues it may identify. In theory, interaction and discussion within the CERED is promoted through its members' participation in working groups (including the Network NGOs) but, in practice, its institutional activity has been very limited since 2012. Indeed, the ECRI has warned that the CERED's structural and financial dependence from government has 'seriously compromised [its] sustainability' and, consequently, '[it] has almost ceased to exist' (ECRI, 2018b, para. 25). ${ }^{118}$

At the top level, EBs can also enhance their responsiveness by taking a co-ordinating role (Table 1, 3.B). EBs can be 'equality hubs' that unite antidiscrimination assistance efforts and build on the work of local organisations to address systemic discrimination. This has been the case in Spain thanks to the partnership between the CERED and FSG. ${ }^{119}$ For instance, in the framework of a local plan to boost employment in Mérida, a clothing-store manager contacted by the City Council overtly stated that he 'didn't want Roma' as trainees; consequently, the store was excluded from the programme (FSG, 2011, p. 35). In other cases in which Roma have been discriminated against in access to or in employment, FSG has persuaded local employers to change these practices (FSG, 2012, p. 41). In contrast, the EHRC has more difficulties in playing a similar informal networking role at the grass-roots level due to the lack of local branches and its limited contact with local civil-society organisations. ${ }^{120}$ Furthermore, the fact that the Network access points work under the CERED's umbrella has the advantage that complaint data are collected following standardised criteria and published in the CERED's annual reports, which facilitates monitoring. Whilst the EHRC may have some contact with discrimination assistance providers (e.g. Law Centres, Citizens Advice Bureaux, Community Legal Advice Centres), the latter collect data following their own procedures and publish their own reports, which are more difficult to consolidate and compare.

In summary, awareness about the CERED in Spain is lower compared to the EHRC's awareness in Britain, but the former has recently made efforts to increase its 'bottom responsiveness' to discrimination through active dissemination of its services and accessible assistance (including face-to-face). Whilst the level of complaints received by the CERED Network is still low, it peaked from 235 complaints in 2010 (SAV, 2015, p. 17) to 853 in 2016 (FSG, 2017). In contrast, the EHRC is not directly accessible by individuals. While the EASS offers assistance through a range of channels and it receives an average of 2,200 calls per month (House of Lords, 2016, p. 52), the potential to increase the EHRC's 'bottom responsiveness' seems limited by the lack of both regular contact with vulnerable communities

\footnotetext{
${ }^{116}$ The CERED Network also engages with other relevant organisations (e.g. the Labour Inspectorate, Hate Crime Prosecutors, Police Forces and the Madrid Bar Council) (FSG, 2017).

${ }^{117}$ RD 1267/2007, Art. 3.

${ }^{118}$ In 2014, its last president resigned in protest against the lack of effectiveness and weak institutional position of the Council' (ACFC, 2014, p. 7) and a new president was not appointed until October 2018; see 'El gobierno recupera el normal funcionamiento del Consejo para la Eliminación de la Discriminación Racial o Étnica', available at https://www.mpr.gob.es/ igualdad/Paginas/2018/251018-racial.aspx (accessed 5 March 2021).

${ }^{119}$ See also Grigolo (2013).

${ }^{120}$ The EHRC has been criticised for 'rarely engag[ing]' with other organisations (House of Lords \& House of Commons, JCHR, 2009-2010, Evidence 74, 77).
} 
and face-to-face assistance. On the other hand, unlike the EHRC, the CERED's weakness lies in its lack of powers to represent complainants and to undertake strategic litigation, which limit its 'top responsiveness' to 'capitalise' the information gathered at the bottom. On the whole, both the EHRC and the CERED lack key elements to effectively address systemic discrimination and be responsive at the top. The EHRC has more 'teeth' to take action when structural discrimination is identified but it does not use its enforcement powers often enough (WEC, 2019, p. 15) and it lacks strong links with civil society to become an 'equality hub' and to identify strategic cases, whereas the CERED has stronger local links but lacks the tools to act in its own name.

\section{Learning the lessons and looking ahead: the 2018 Recommendation's potential to encourage more responsive EBs}

This paper has argued that EBs matter to respond to discrimination. They are not the panacea, but they are one of the fundamental enforcement tools that can be used to effectively address discrimination. ${ }^{121}$ To do so, however, they must be well designed and resourced, in line with the 'Responsiveness Framework' developed in section 2. When this is the case, they can be key players in addressing discrimination, both by proactively promoting equal treatment ('top responsiveness') and by supporting vulnerable individuals to react more autonomously to discrimination ('bottom responsiveness'). In the European context, the RED paved the way for and importantly contributed to the development of a critical mass of European equality 'watchdogs'. ${ }^{122}$ Yet, its vague standards regarding EBs have allowed MS to fully comply with EU law by setting up, in many cases, largely unresponsive EBs (section 3).

This has been illustrated through the comparison of the British EB, the EHRC and the Spanish EB, the CERED (section 4). This case-study confirms that being independent and having sufficient resources are crucial prerequisites for EBs' responsiveness. Both the examples of the CERED and the EHRC demonstrate that, if resources are scarce or significantly reduced, EBs' effectiveness tends to be negatively affected. Yet, resources - on their own - are not sufficient to ensure EBs' responsiveness. The CERED's extremely low budget does not allow an independent institutional structure and strategic enforcement powers. The EHRC has a higher level of resources but, following the post-Recession budget cuts, its helpline was subcontracted and it lost its direct interface with the public. Still, the EHRC continues to be one of the best-resourced bodies in Europe, but the CERED arguably has a better assistance system at the grass-roots level, despite the latter's acute lack of resources.

The comparison between these two bodies also shows that bottom and top responsiveness are interlinked ${ }^{123}$ and are necessary for EBs to effectively address discrimination. The CERED's institutional design for assistance provision facilitates bottom responsiveness but its top responsiveness is very limited due to its lack of legal personality and strategic enforcement powers. The EHRC has systemic enforcement powers that better support top-level responsiveness, but its lack of direct contact with the public weakens its bottom responsiveness and limits its ability to build on individual complaints for its top-responsiveness activities.

Cognisant of the problems that this case-study exemplifies, the EU adopted the 2018 Recommendation to supplement the loose provisions of the RED and to encourage the design of more effective national EBs. ${ }^{124}$ A key question is then: Has this Recommendation the potential to trigger changes in EBs institutional architecture that could boost their responsiveness to discrimination? Overall, the Recommendation builds on existing EB literature and most of the international benchmarks considered in section $2,{ }^{125}$ so the standards proposed largely correspond to the 'Responsiveness Framework'. ${ }^{126}$ The main virtues of the Recommendation are, therefore, that it aligns

\footnotetext{
${ }^{121}$ On other tools and the need to take a comprehensive approach to tackle discrimination, see e.g. Solanke (2017, chapter 5).

${ }^{122}$ Together with the other additional Directives; see note 7 above.

${ }^{123}$ Similarly, see Crowley (2018, p. 55).

${ }^{124}$ See also Crowley and Gaspard (2018).

${ }^{125}$ Recommendation, note 7 , at 15-17.

${ }^{126}$ All the subdimensions from the Responsiveness Framework are expressly dealt with in the Recommendation.
} 
EU law with most international best practice and it finally sets out much more clearly what is expected from MS when implementing their duty to set up EBs. This is a significant step forward, but the Recommendation's language is still fairly broad and flexible, particularly for standards on independence, support for victims and accessibility. ${ }^{127}$ For example, the Recommendation only demands that MS 'should take into consideration the following aspects of providing independent assistance: receiving and handling individual or collective complaints; providing legal advice to victims, including in pursuing their complaints'; it indicates that 'assistance to victims can include granting equality bodies the possibility to engage or assist in litigation' and that MS 'should consider enabling [EBs] to establish local and/or regional offices ... or local and/or regional outreach initiatives'. ${ }^{128}$ Thus, MS may comply with the Recommendation even if the national EB does not provide legal advice and does not have any regional or local presence. Considering the Recommendations' uncompelling language and its soft-law nature, the EU will probably need to proactively encourage its implementation and even consider binding measures to stimulate MS to introduce meaningful changes. ${ }^{129}$

In a context in which the BlackLivesMatter movement has brought systemic racism to the attention of the public worldwide and the COVID-19 pandemic is hitting ethnic minorities hard (Devakumar et al., 2020), EBs can matter more than ever as part of wider public efforts to address racial and ethnic-origin discrimination if they are designed responsively. The Recommendation has some potential to be a stepping stone to trigger positive changes in national EBs architecture, but it is doubtful that MS will take it seriously enough to make a difference in practice.

Conflicts of Interest. None

Acknowledgements. I am grateful to Mark Bell, David Gurnham, Harry Annison, Matthew Nicholson and the two anonymous reviewers for their helpful comments on earlier versions of this article. The usual disclaimers apply.

\section{References}

ABA (American Bar Association) (2002) Model Rules of Professional Conduct as Adopted by ABA House of Delegates. Chicago: ABA.

ACFC (Advisory Committee on the Framework Convention for the Protection of National Minorities), Council of Europe (2014) Fourth Opinion on Spain adopted on 3 December 2014, ACFC/OP/IV(2014)003.

Alderson R (2015) Survey finds a third of black and ethnic minority Scots experience discrimination, BBC, 14 September. Available at https://www.bbc.co.uk/news/uk-scotland-34220544 (accessed 20 February 2018).

Alfinito Vieira A and Graser A (2015) Taming the biased black blox? On the potential role of behavioural realism in antidiscrimination policy. Oxford Journal of Legal Studies 35, 121-152.

Ambrus M (2012) Enforcement Mechanisms of the Racial Equality Directive and Minority Protection. The Hague: Eleven.

Ammer M et al. (2010) Study on Equality Bodies set up under Directives 2000/43/EC, 2004/113/EC2 and 2006/54/EC: Synthesis Report. Brussels: European Human Consultancy, Ludwig Boltzmann Association and Institute of Human Rights (BIM).

Anderson E (1999) What is the point of equality? Ethics 109, 287-337.

Aston J, Hill D and Tackey ND (2006) The Experience of Claimants in Race Discrimination Employment Tribunal Cases. London: Department for Trade and Industry.

Balmer N et al. (2012) Just a phone call away: is telephone advice enough? Journal of Social Welfare and Family Law 34, 63-85.

Barmes L (2016) Bullying and Behavioural Conflict at Work: The Duality of Individual Rights. Oxford: OUP.

Barry E (2003) Different hierarchies - enforcing equality law. In Costello C and Barry E (eds), Equality in Diversity: The New Equality Directives. Dublin: Irish Centre for European Law/Equality Authority, pp. 411-434.

Bell M (2001) Meeting the challenge? A comparison between the EU racial equality directive and the starting line. In Chopin I and Niessen J (eds), The Starting Line and the Incorporation of the Racial Equality Directive into National Laws of the EU Member States and Accession States. Brussels: MPG, pp. 22-54.

Bell M (2008) Racism and Equality in the European Union. Oxford: OUP.

Ben-Cnaan B (2016) An equality helpline that works! Available at www.crowdjustice.com (accessed 20 November 2018).

\footnotetext{
${ }^{127}$ See a more detailed critique in Benedi Lahuerta (forthcoming in 2022).

${ }^{128}$ Paras 1.1.2, 1.2.3, emphases added.

${ }^{129}$ An option envisaged in the 2020 EU Action Plan to Combat Racism (COM(2020) 265 final, p. 4).
} 
Ben-Ishai E (2012) The new paternalism: an analysis of power, state intervention, and autonomy. Political Research Quarterly 65, 151-165.

Benedi Lahuerta S (2014) The effectiveness of the EU race equality directive at national level: a comparative study of British and Spanish legislation and policies. Unpublished $\mathrm{PhD}$ thesis. University of Leicester, Leicester. Available at https://leicester.figshare.com/articles/thesis/

The_effectiveness_of_the_EU_race_equality_directive_at_national_level_A_comparative_study_of_British_and_Spanish_legislation_and_policies/10152260/1 (accessed 6 September 2018).

Benedi Lahuerta S (2020) Has the EU taken comprehensive and coherent action to combat discrimination? In Giegerich T (ed.), The European Union as Protector and Promoter of Equality. Cham: Springer, pp. 165-184.

Benedi Lahuerta S (forthcoming in 2022) Equality bodies in the EU: origins, challenges and future prospects. In O'Cinneide C, Ringelheim J and Solanke I (eds), Edward Elgar Research Handbook on European Anti-discrimination Law. Cheltenham: Edward Elgar.

Bleich E (2003) Race Politics in Britain and France: Ideas and Policymaking since the 1960s. Cambridge: CUP.

Blodorn A and O'Brien LT (2013) Evaluations of White American versus Black American discrimination claimants' political views and prejudicial attitudes. Journal of Experimental Social Psychology 49, 211-216.

Boothman C and MacEwen M (1997) The British Commission for Racial Equality as an enforcement agency. In MacEwen M (ed.), Anti-discrimination Law Enforcement: A Comparative Perspective. Aldershot: Avebury, pp. 155-173.

Buck A and Curran L (2009) Delivery of advice to marginalised and vulnerable groups: the need for innovative approaches. Public Space: The Journal of Law and Social Justice 3, 1.

Busby B and McDermont M (2012) Workers, marginalised voices and the employment tribunal system: some preliminary findings. Industrial Law Journal 41, 166-183.

CoE (Council of Europe) Commissioner for Human Rights (2011) Opinion on National Structures for Promoting Equality. CommDH(2011)2. Strasbourg: CoE.

Crowley N (2016) Merging mandates of equality bodies and national human rights institutions - a growing trend. European Equality Law Review 2, 34-45.

Crowley N (2018) Equality Bodies Making a Difference. Luxembourg: POEU.

Crowley N and Gaspard A (2018) Minding equality bodies. Juridikum 3, 323-331.

Crowther N and O'Cinneide C (2019) Bridging the divide? Integrating the functions of national equality bodies and national human rights institutions in the European Union. Juridikum 2, 210-221.

DCMS (Department for Culture Media \& Sport) and EHRC (2015) Framework Document. Available at https://assets.publishing.service.gov.uk/government/uploads/system/uploads/attachment_data/file/416426/EHRCGEO_Framework_March_2015.pdf (accessed 10 November 2018).

De Witte B (2011) New institutions for promoting equality in Europe: legal transfers, national bricolage and European governance. American Journal of Comparative Law 60, 49-74.

Devakumar D et al. (2020) Racism and discrimination in COVID-19 responses. The Lancet, published online 11 April. Available at https://doi.org/10.1016/S0140-6736(20)30792-3 (accessed 5 March 2021).

EASS (2017) Engagement Newsletter. March. Available at www.equalityadvisoryservice.com (accessed 15 January 2018).

EASS (2018) Advice: Support and Resources. Available at www.equalityadvisoryservice.com/app/help (accessed 15 January 2018).

ECRI (1997) General Policy Recommendation. No. 2 1997. CRI (97) 36. Strasbourg: ECRI.

ECRI (2010) Report on the United Kingdom: Fourth Monitoring Cycle. CRI(2010)4. Strasbourg: ECRI.

ECRI (2011) Report on Spain: Fourth Monitoring Cycle. CRI(2011)4. Strasbourg: ECRI.

ECRI (2018a) General Recommendation No. 2, Equality Bodies to Combat Racism and Intolerance at National Level. CRI (2018)06. Strasbourg: ECRI.

ECRI (2018b) Report on Spain: Fifth Monitoring Cycle. CRI(2018)2. Strasbourg: ECRI.

EHRC (2009) Two Years Making Changes. London: EHRC.

EHRC (2018) Annual Report and Accounts 2017/18. London: House of Commons.

EHRC (2019) Workforce Diversity Report 2018 to 2019. London: EHRC.

ENAR (2018) Shadow Report on Racism \& Discrimination in Employment in Europe 2013-2017. Brussels: ENAR.

Equinet (2010) Influencing the Law through Legal Proceedings: The Powers and Practices of Equality Bodies. Brussels: Equinet.

Equinet (2012) Equality Bodies Current Challenges: An Equinet Perspective. Brussels: Equinet.

Equinet (2016) Developing Standards for Equality Bodies: An Equinet Working Paper. Brussels: Equinet.

Equinet (2018) Spain: Council for the Elimination of Racial or Ethnic Discrimination. Available at http://www.equineteurope. org/Race-and-Ethnic-Equality-Council (accessed 10 February 2018).

EU Commission (2018) A Europe that protects: commission calls for stronger national Equality Bodies to fight discrimination. 22 June. Press release IP/18/4000.

Farrell M (2013) Seminar with National Specialised Bodies to combat Racism and Racial Discrimination: Challenges Faced in the Current Institutional and Budgetary Environment: Summary and Conclusions. Strasbourg: ECRI.

Feagin F (2013) Systemic Racism: A Theory of Oppression. Abingdon: Routledge. 
Felstiner WLF (1974) Influences of social organization on dispute processing. Law \& Society Review 9, 63.

Fineman MA (2008) The vulnerable subject: anchoring equality in the human condition. Yale Journal of Law and Feminism 20, 1-23.

FRA (2010) EU Midis 2009. EU Minorities and Discrimination Survey: Main Results Report. Luxembourg: EUPO.

FRA (2012) The Racial Equality Directive: Application and Challenges. Luxembourg: POEU.

FRA (2017) EU Minorities and Discrimination Survey II: Main Results Report. Luxembourg: POEU.

Fredman S (2012) Discrimination Law, 2nd edn. Oxford: OUP.

FSG (2011) Informe Anual 2011: Discriminación y Comunidad Gitana. Madrid: FSG.

FSG (2012) Informe Anual 2012: Discriminación y Comunidad Gitana. Madrid: FSG.

FSG (2017) Informe Anual 2016: Discriminación y Comunidad Gitana. Madrid: FSG.

García Añón J and Ruiz Sanz M (eds) (2013) Discriminación racial y étnica: Balance de la aplicación y eficacia de las garantías normativas. Valencia: Tirant lo Blanch.

Genn H (1999) Paths to Justice: What People Do and Think about Going to Law. Oxford: OUP.

GEO (2011) Information, Advice and Support on Equality and Human Rights Issues. London: GEO.

Givens TE and Case RE (2014) Legislating Equality: The Politics of Antidiscrimination Policy in Europe. Oxford: OUP.

Griffith A and Burton M (2011) From face-to-face to telephone advice? Legal Action 6, 7. Available at asauk.org.uk/ wp-content/uploads/2013/09/AGfeatureFeb11.pdf (accessed 20 May 2018).

Grigolo M (2013) Incorporating cities into the EU anti-discrimination policy: between race discrimination and migrant rights. In Moschel M, Hermanin C and Grigolo M (eds), Fighting Discrimination in Europe: The Case for a Race-conscious Approach. London: Routledge, pp. 115-133.

Hepple B (2012) Agency enforcement of workplace equality. In Dickens L (ed.), Making Employment Rights Effective: Issues of Enforcement and Compliance. London: Hart, pp. 49-66.

Hepple B (2014) Equality: The Legal Framework, 2nd edn. London: Hart.

HM Government (2018) Tailored Review of the Equality and Human Rights Commission. London: HM Government.

Holtmaat R (2006) Catalysts for Change? Equality Bodies According to Directive 2000/43/EC: Existence, Independence and Effectiveness. Luxembourg: POEU.

House of Lords \& House of Commons, JCHR (Joint Committee on Human Rights) (2009-2010) Equality and Human Rights Commission: 13th Report of Session 2009-10. London: House of Lords \& House of Commons.

House of Lords, Select Committee on the Equality Act 2010 and Disability (2016) The Equality Act 2010: The Impact on the Disabled People. Report of Session 2015-16. HL Paper 117.

ICHRP (International Council for Human Rights Policy) (2005) Assessing the Effectiveness of National Human Rights Institutions. Versoix: Office of the United Nations High Commissioner for Human Rights.

INE (Instituto Nacional de Estadística) (2017) Cifras de Población a 1 de enero de 2017. Estadística de Migraciones 2016 (provisionales). Available at www.ine.es/prensa/prensa.htm (accessed 1 July 2018).

Jacobsen BD (2010) Assistance to Victims of Discrimination by Equality Bodies of the EU Member States - a Scandinavian Perspective. Copenhagen: DJØF Publishing.

Kádár T (2018) Equality Bodies: a European phenomenon. International Journal of Discrimination and the Law 18, 144-162.

MacEwen M (1997) Promoting equal opportunity: the enforcement agency. In MacEwen M (ed.), Anti-discrimination Law Enforcement: A Comparative Perspective. Farnham: Ashgate.

Mackenzie C (2014) The importance of relational autonomy and capabilities for an ethics of vulnerability. In C Mackenzie et al. (eds), Vulnerability: New Essays in Ethics and Feminist Philosophy. Oxford: OUP, pp. 33-59.

Macpherson W (1999) The Stephen Lawrence Inquiry: Report of an Inquiry. London: Home Office.

Martínez FR (2014) Racismo líquido. Claves de razón práctica 237, 88-95.

McColgan A (2014) Discrimination, Equality and the Law. Oxford: Bloomsbury.

O'Cinneide C (2007) The Commission for Equality and Human Rights: a new institution for new and uncertain times. Industrial Law Journal 36, 141-162.

ONS (Office for National Statistics) (2018) Population Estimates for UK, England and Wales, Scotland and Northern Ireland: Mid-2017. Available at https://www.ons.gov.uk/peoplepopulationandcommunity/populationandmigration/populationestimates/datasets/populationestimatesforukenglandandwalesscotlandandnorthernireland (accessed 25 November 2018).

Oxford English Dictionary (2018) Available at www.oed.com (accessed 25 July 2018).

Parraudin F (2018) Roma communities fear deportation in post-Brexit Britain, The Guardian, 2 July.

Pleasence PT, Balmer NJ and Sandefur RL (2013) Paths to Justice: A Past, Present and Future Roadmap. London: UCL Centre for Empirical Legal Studies.

Ramírez J and Chinchón Álvarez J (2007) Obstáculos para el acceso a la justicia en casos de discriminación étnica-racial. In Acción contra la discriminación: 612 casos de discriminación en territorio español. Madrid: Women's Link Worldwide S.O.S. Racismo, pp. 36-53.

Read S (2014) G4S faces fury over human rights abuses, The Guardian, 6 June.

RED2RED (2011) Panel sobre discriminación por origen racial o étnico (2010): la percepción de las potenciales víctimas. Madrid: Ministerio de Sanidad, Política Social e Igualdad. 
Renton D (2015) Struck Out: Why Employment Tribunals Fail Workers and What Can Be Done. London: Pluto Press.

Rhode DL (1990) The delivery of legal services by non-lawyers. Georgetown Journal of Legal Ethics 4, 209-233.

Robeyns I (2018) The capability approach. In Olsaretti S (ed.), The Oxford Handbook of Distributive Justice. Oxford: OUP, pp. 109-128.

SAV (Servicio de Asistencia a Víctimas de Discriminación Racial y Étnica) (2012) Memoria Anual de Resultados 2011. Madrid: CERED.

SAV (2015) Memoria Anual de Resultados 2014. Madrid: CERED.

SAV (2016) Informe de resultados 2016. Madrid: CERED.

Seneviratne M (2005) Researching ombudsmen. In R Banakar and M Travers (eds), Theory and Method in Socio-legal Research. Oxford: Hart Publishing, pp. 161-174.

Siddique H (2020) Politicising the EHRC? Five controversial appointments, The Guardian, 20 November.

Smith N (2011) Basic Equality and Discrimination: Reconciling Theory and Law. Farnham: Ashgate.

Solanke I (2009) The Evolution of Anti-discrimination Law in the UK, Germany and the EU. Abingdon: Routledge.

Solanke I (2017) Discrimination as Stigma: A Theory of Anti-discrimination Law. Oxford: Bloomsbury.

Tyson A (2001) The negotiation of the European community directive on racial discrimination. European Journal on Migration and Law 3, 199-229.

Van Ballegooij W and Moxom J (2018) Equality and the Fight against Racism and Xenophobia: Cost of Non-Europe Report. Brussels: European Parliamentary Research Service.

Verloo M et al. (2012) Putting intersectionality into practice in different configurations of equality architecture: Belgium and the Netherlands. Social Politics: International Studies in Gender, State \& Society 19, 513-538.

WEC (Women Equalities Committee), House of Commons (2018) Oral Evidence: The Work of the Equality and Human Rights Commission. HC 357.

WEC (2019) Enforcing the Equality Act: The Law and the Role of the Equality and Human Rights Commission. HC 1470.

Widdison R (2003) Electronic paths to justice. Journal of Information, Law and Technology 3. Available at http://elj.warwick. ac.uk/jilt/03-2/widdison.html (accessed 30 May 2018).

Yesilkagit K and Snijders B (2008) Between Impartiality and Responsiveness: Equality Bodies and Practices of Independence. Brussels: Equinet.

\section{Appendix: Interviews' overview}

\begin{tabular}{|c|c|c|c|c|c|c|c|}
\hline & Interviewee* & $\begin{array}{l}\text { Interview } \\
\text { date }\end{array}$ & $\begin{array}{l}\text { Legal } \\
\text { expert/ } \\
\text { professional }\end{array}$ & $\begin{array}{l}\text { Equality } \\
\text { body }\end{array}$ & $\begin{array}{l}\text { Trade } \\
\text { union }\end{array}$ & Business & $\begin{array}{l}\mathrm{CSO} / \\
\mathrm{NGO}\end{array}$ \\
\hline \multirow[t]{7}{*}{ BRITAIN } & $\begin{array}{l}\text { 1. Mr Robin Allen (Cloisters' } \\
\text { partner, Barrister specialising } \\
\text { in antidiscrimination law) }\end{array}$ & $15 / 2 / 2013$ & $x$ & & & & \\
\hline & $\begin{array}{l}\text { 2. Ms Barbara Cohen } \\
\text { (discrimination law expert, } \\
\text { consultant and former legal } \\
\text { officer at the Commission for } \\
\text { Racial Equality) }\end{array}$ & $6 / 12 / 2012$ & $x$ & & & & \\
\hline & $\begin{array}{l}\text { 3. Ms Wendy Hewitt (Deputy } \\
\text { Legal Director, EHRC) }\end{array}$ & $29 / 3 / 2013$ & & $x$ & & & \\
\hline & $\begin{array}{l}\text { 4. Ms Gay Moon (Special Legal } \\
\text { Adviser at 'Equally Ours'**) }\end{array}$ & $29 / 2 / 2013$ & & & & & $x$ \\
\hline & $\begin{array}{l}\text { 5. Mr Wilf Sullivan (Race Equality } \\
\text { Officer at TUC) }\end{array}$ & $29 / 3 / 2013$ & & & $x$ & & \\
\hline & $\begin{array}{l}\text { 6. Immigration \& } \\
\text { antidiscrimination officer } \\
\text { (Citizens' Advice Bureau) }\end{array}$ & $6 / 6 / 2018$ & & & & & $x$ \\
\hline & $\begin{array}{l}\text { 7. Employment policy advisers } \\
\text { (Confederation of British } \\
\text { Industry, CBI) }\end{array}$ & $17 / 6 / 2013$ & & & & $x$ & \\
\hline
\end{tabular}

(Continued) 
Appendix: (Continued.)

\begin{tabular}{|c|c|c|c|c|c|c|c|}
\hline & Interviewee* & $\begin{array}{l}\text { Interview } \\
\text { date }\end{array}$ & $\begin{array}{l}\text { Legal } \\
\text { expert/ } \\
\text { professional }\end{array}$ & $\begin{array}{l}\text { Equality } \\
\text { body }\end{array}$ & $\begin{array}{l}\text { Trade } \\
\text { union }\end{array}$ & Business & $\begin{array}{l}\mathrm{CSO} / \\
\mathrm{NGO}\end{array}$ \\
\hline \multirow[t]{7}{*}{ SPAIN } & $\begin{array}{l}\text { 1. Mr Miguel Ángel Aguilar } \\
\text { (Barcelona Public Prosecutor } \\
\text { against Hate Crime) }\end{array}$ & $20 / 4 / 2013$ & $x$ & & & & \\
\hline & $\begin{array}{l}\text { 2. Civil servant (Spanish Racial } \\
\text { Equality Council, SREC) }\end{array}$ & $19 / 4 / 2013$ & & $x$ & & & \\
\hline & $\begin{array}{l}\text { 3. Ms Sara Giménez (Lawyer, } \\
\text { Equality Director at } \\
\text { Fundación Secretariado } \\
\text { Gitano, FSG) }\end{array}$ & $23 / 4 / 2013$ & $x$ & & & & $x$ \\
\hline & $\begin{array}{l}\text { 4. Ms Guadalupe Pulido } \\
\text { (Director of 'Oficina Per la No } \\
\text { Discriminación', } \\
\text { Anti-discrimination \& Human } \\
\text { Rights Office, Barcelona City } \\
\text { Council) }\end{array}$ & $20 / 4 / 2013$ & & $x$ & & & \\
\hline & $\begin{array}{l}\text { 5. Ms Katrina Belsué (Lawyer, } \\
\text { Discrimination Helpdesk } \\
\text { Director, Sos Racismo } \\
\text { Aragón) }\end{array}$ & $18 / 4 / 2013$ & & & & & $x$ \\
\hline & $\begin{array}{l}\text { 6. Ms Ana Belén Budría } \\
\text { (In-house lawyer at the trade } \\
\text { union 'Comisiones Obreras', } \\
\text { CCOO) }\end{array}$ & $15 / 7 / 2013$ & $x$ & & $x$ & & \\
\hline & $\begin{array}{l}\text { 7. Mr Jose Ignacio Torres } \\
\text { (Employment policy officer at } \\
\text { Conferedation of Small and } \\
\text { Medium Businesses, Social } \\
\text { and Labour Policy } \\
\text { Department, CEPYME) }\end{array}$ & $13 / 11 / 2013$ & & & & $x$ & \\
\hline
\end{tabular}

Cite this article: Benedi Lahuerta S (2021). Equality Bodies: advancing towards more responsive designs? International Journal of Law in Context 17, 390-412. https://doi.org/10.1017/S1744552321000240 